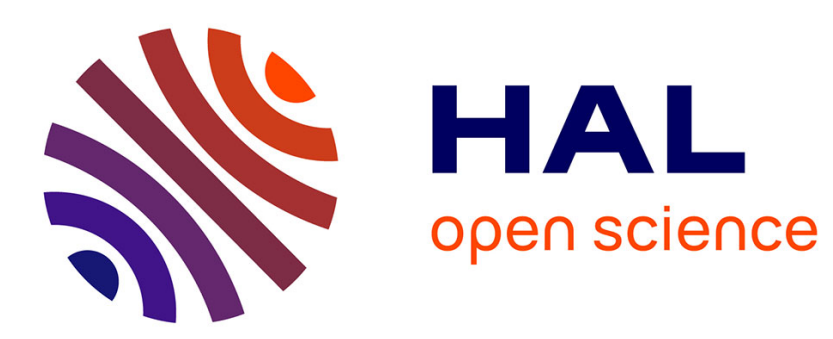

\title{
Christian monasticism on the eve of Islam: Kilwa (Saudi Arabia) - new evidence
}

\author{
Saba Farès
}

\section{To cite this version:}

Saba Farès. Christian monasticism on the eve of Islam: Kilwa (Saudi Arabia) - new evidence. Arabian Archaeology and Epigraphy, 2011, 22 (2), pp.243 - 252. 10.1111/j.1600-0471.2011.00335.x . halshs01728349

\section{HAL Id: halshs-01728349 \\ https://shs.hal.science/halshs-01728349}

Submitted on 24 Sep 2021

HAL is a multi-disciplinary open access archive for the deposit and dissemination of scientific research documents, whether they are published or not. The documents may come from teaching and research institutions in France or abroad, or from public or private research centers.
L'archive ouverte pluridisciplinaire HAL, est destinée au dépôt et à la diffusion de documents scientifiques de niveau recherche, publiés ou non, émanant des établissements d'enseignement et de recherche français ou étrangers, des laboratoires publics ou privés. 


\section{Christian monasticism on the eve of Islam: Kilwa (Saudi Arabia) — new evidence}

Little knowledge and understanding of Kilwa has been acquired since its discovery in the 1930s. Headed by Saba Farès, research began in 2008 which would provide more thorough documentation of the site through an architectural study of the buildings and excavations and by examining the archaeology and epigraphy of the region. A reexamination of Arabic inscriptions engraved on the lintel of a cell has enabled us to decipher a text containing the name of the community that originally lived in Kilwa, providing us with details of their origins. The text in question enables us to understand the architectural similarity between the Kilwa buildings and those in southern Syria and northern Jordan. After two seasons of excavation, it is now certain that the Kilwa site was a monastery. The presence of a large number of crosses on the lintels of the cells confirms the Christian faith of the inhabitants.

Keywords: Kilwa, monasticism, Saudi Arabia, Hima, eastern Christians

\section{Saba Farès}

University of Nancy 2/

GREMMO UMR 5195, France;

22 Quai Tilsitt, 69002 Lyon,

France

\section{Overview}

In 2005, the Vice-Ministry for Antiquities and Museums of Saudi Arabia suggested that I undertake research work in the region of al-Tubayq, to the north-east of Tabūk (Fig. 1). Following an initial visit that year, we decided that it was preferable to excavate the remains of Kilwa and explore the archaeology and epigraphy of the region. In order to organise these works we launched a mission, which ran from 15 to 26 February 2008.

The main goal of this first mission was to assess the feasibility of the fieldwork. A project of this type requires rather complicated logistics, which are difficult to organise if one is not on site. The second goal was to examine the remains and to gather cartographic and photographic documentation in order to prepare the excavation for the following year. The purpose of this article is to present a new vision of the site and how it is laid out. Two excavation campaigns have been under way since 2008 : this article is a presentation of the 2008 campaign, that of 2009 is presently being printed and will appear in ATLAL 2010. The report on the 2010 campaign is also being prepared for publication.

The mission's members were:
French members:

Olivier Barge, cartographer, CNRS, Maison de l'Orient, Lyon;

Saba Farès, epigraphist, head of the project, University of Nancy 2, UMR 5189, Lyon;

Pierre-Louis Gatier, archaeologist-epigraphist, CNRS, UMR 5189, Lyon;

Julien Christian Robin, epigraphist, UMR 8167 Orient et Méditerranée, Paris.

Saudi members:

Hmoud Al-'Nizī, cartographer, Commission for

Tourism;

Khālid Iskūbī, Commission for Tourism, Riyadh.

Accompanied by:

Sa'̄id 'īd al-'tiwīi, driver for the Department of Antiquities;

Salamh 'îd al-'tiwī, driver for the Department of Antiquities;

Ya'rub Ḥassan Al-'alī, Director of Tabūk Antiquities.

The mission was financed by the Human Sciences and Archaeology Division of the Ministry of Foreign Affairs in 


\section{SABA FARÈS}

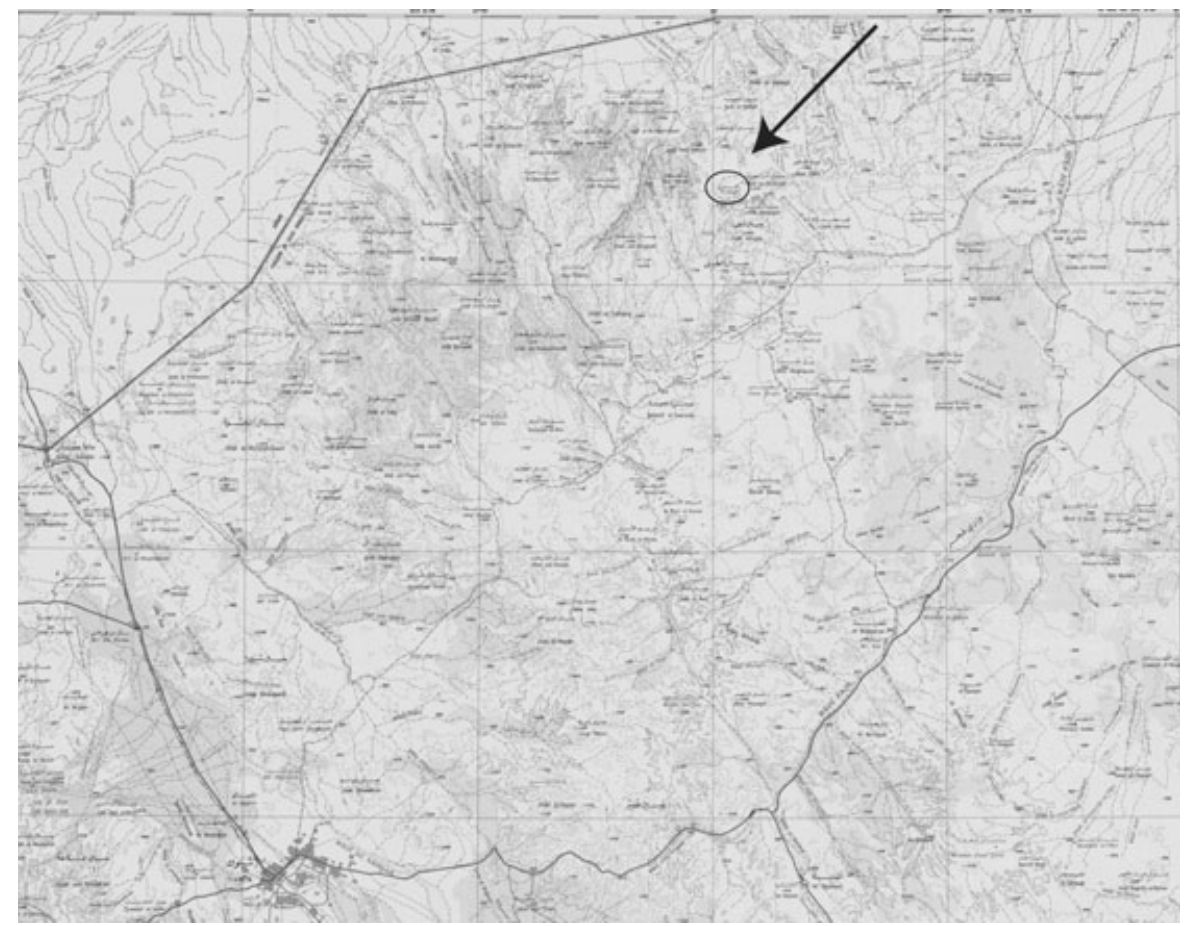

Fig. 1.

Map of Tabūk.

France, the Cooperation and Cultural Action Service of the French Embassy in Saudi Arabia and the High Commission for Tourism in Saudi Arabia.

Kilwa [29 41'58.91"N/37 31'58.71"E] is located approximately $250 \mathrm{~km}$ from Tabūk (see Fig. 1). The site lies in the hilly region of al-Tubayq. To reach Kilwa from Tabūk, one has to follow the Quyrayyât road. After 175 $\mathrm{km}$, at the al-Fajr police post, one enters the desert and heads north to Kilwa, located $80 \mathrm{~km}$ further on. Another police post, al-Moughayra, is located halfway between the al-Fajr and Kilwa police posts. In Kilwa, there is only the Tabūk Principality guardroom, presently occupied by Salmān Farhāan al-Shrārī and the guardian of the site, $\mathrm{Mr}$ Lāzim Mas'ūd al-Shrārī.

The surface defined by the Department of Antiquities covers an area $800 \mathrm{~m}$ long and $400 \mathrm{~m}$ wide containing 'the monks' cells' and a building for collective use (water system, refectory, etc). Half of its north-eastern part is abandoned and there are no buildings there (Fig. 2).

Gertrude Bell was the first person to submit a report concerning the existence of remains in Kilwa, following a journey through the area in 1914 on her way to Hā'il. In the article in which she describes her journey she reported the existence of the Kilwa remains without naming the place: 'and in the Jebel Tubayq I found another station, doubtless upon the same caravan route' (Bell 1914: 7677). In December 1932, George Horsfield, Director of Antiquities in Transjordan, Agnes Horsfield and Nelson Glueck, Director of the American School of Oriental Research in Jerusalem, organised a trip to Kilwa and described in particular the rock engravings surrounding Kilwa (Horsfield, Horsfield \& Glueck 1933: 381-386). An article published by Glueck focused principally on the monastery (Glueck 1936: 9-16). Some years later, Agnes Horsfield also published an article devoted to the Kilwa remains (Horsfield A 1943: 71-77). According to her, the name of Kilwa comes from the Greek $\kappa \varepsilon \lambda \lambda$ 1ov, which designates 'the kellia, the place for meditation' (1943: 74). The meaning is the same in Arabic, constituting a reference to the Arabic Hilwa خلوة 'the isolated place'. For Horsfield, given the name of the site and the layout of the remains, the latter were hermitage cells for monks. The presence of the Kufic inscription on the lintel of one of the cells indicates that the site dates from AD 1000 (Horsfield, Horsfield \& Glueck 1933: 381).

It is mostly due to its prehistoric remains and its rock engravings, some of which appear to be the most ancient of the Near East (Zarins 1990: 31-64; Howe 1950: 8-17), 


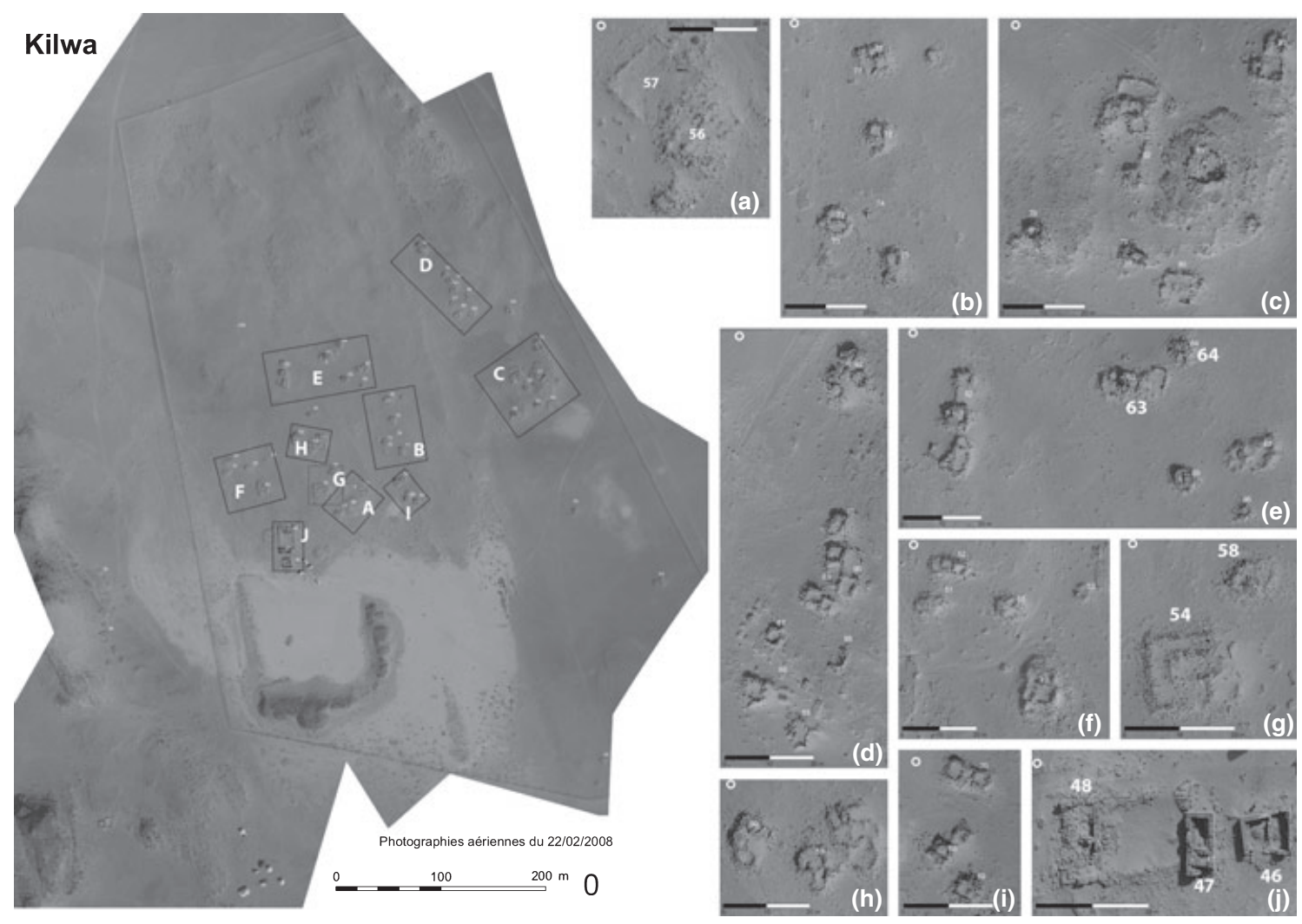

Fig. 2.

View of the Kilwa remains.

that Kilwa has attracted the attention of pre-historians. A German expedition was organised in 1938 and resulted in a publication by Hans Rhotert (1938). Aurel Stein attempted to visit Kilwa, but his mission was cut short due to bad weather (1940: 435). The Department of Antiquities in Arabia plotted the site while registering archaeological sites in the 80s (Ingraham et al. 1981: 5983). Kilwa was then classified among the prehistoric sites (Breasted \& Debevoise 1934: 184). It became famous as such, with its prehistoric rock engravings considered to be among the most ancient discovered so far (al-Taymān̄̄ et al. 2003: 122-123). For some scholars, Kilwa would appear to be a Roman-Byzantine police post (Sartre 1981: 86; Graf 1999: 230-234), dating, according to Glueck, from the sixth century AD (1936: 6-16).

A mere glimpse at all these publications reveals that little is known about Kilwa despite the fact that the site appears to be rich in historical elements which greatly further our understanding of the period of the expansion of Islam. D. Graf has argued that limited knowledge of Kilwa is the reason why the site is not mentioned in the Madaba Map (1999: 233).
While carrying out this work, the first questions that concerned us were: how was this community able to survive in such an environment and who were they exactly? Consequently, before starting excavation, it was necessary to begin by identifying the buildings and assessing the dimensions of the site. Considering the large surface area occupied by the remains, it was essential to take aerial photographs and a 'pixy' plane (Fig. 3), equipped with a digital camera, was used for this purpose. These photographs would provide the basis for the topographic plotting which was to take place before excavation began during the following campaign. Due to a permanent wind, we were unable to fly over the site for as long as we had originally intended, but we made the most of a short lull in the early morning to achieve our goal. The wind would pick up at around $11 \mathrm{a} . \mathrm{m}$. and we would then go prospecting. The task was not only limited to touring around with the plane, as the photographs thus acquired were to be integrated in a Geographical Information System. For this reason we had to identify the remains, leave marks on the ground (coloured plates) on all remains visible in the pictures and record all the marks made on the 


\section{SABA FARÈS}

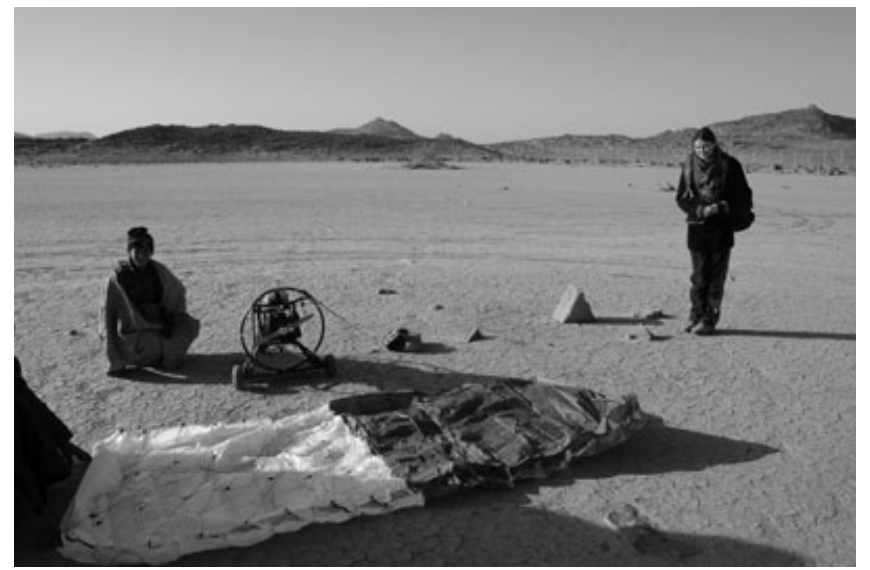

Fig. 3.

The 'pixy' plane.

remains by referential GPS. The aerial pictures enabled us to identify other remains not visible to the naked eye, which enlightened us as to the extent of the settlement.

Thanks to this identification work on the Kilwa settlement and its region, we were able to understand the geographic dimension and to formulate many questions concerning human occupation, local communication means, resource management, etc. Below is a geographic description of Kilwa and its region, which provides us with the opportunity to introduce several hypotheses.

\section{The site of Kilwa and its surroundings}

\section{Geographic description}

Very friable sandstone hills, about $100 \mathrm{~m}$ high, emerge from a plain approximately $900 \mathrm{~m}$ above sea level. These hills, composed mainly of limestone, are scattered over the plain extending towards the east and the northeast. Viewed by satellite, the site is revealed to be a natural alluvium deposit backing onto a hill, approximately $800 \mathrm{~m}$ long, to the north-east (Fig. 4). The hills bordering the southern end of the site face south-eastnorth-west and rise gradually to culminate here and there at about $200 \mathrm{~m}$. Al-qâa', the main depression lying at the southern limit of the site, forms a collecting zone for water coming from the wadis flowing from the northwest.

\section{The actual Kilwa SITE}

The remains of Kilwa constitute a rather dense settlement with the major concentration of constructions located to the west (see Fig. 4). The buildings form heaps of varied dimensions. A group of buildings stands out architecturally. It is made up of five constructions in the centre of which, on a higher level, stands a round house whose eastern part is shortened, bringing to mind an apse. The architecture of this building and the fact that it is placed at a greater height and faces east suggests the presence of a

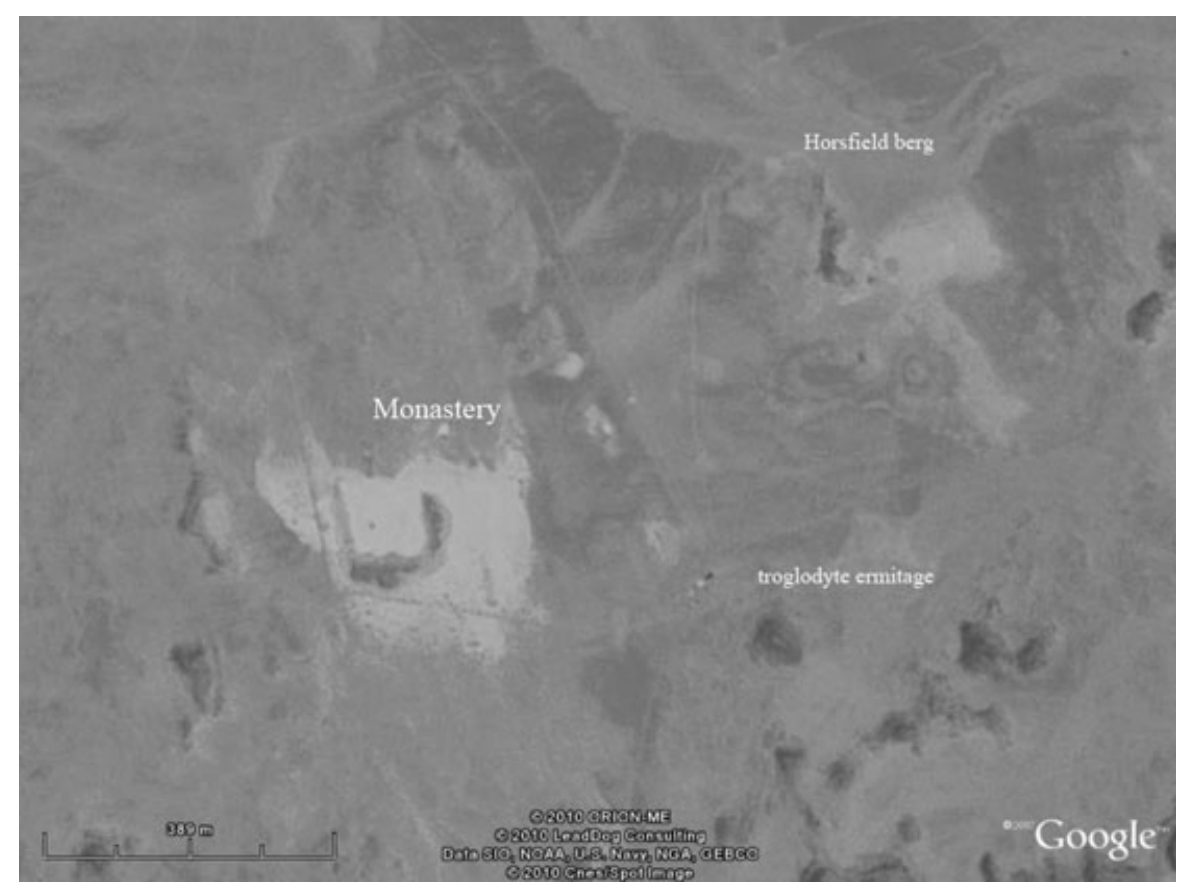

Fig. 4.

Satellite view of Kilwa. 


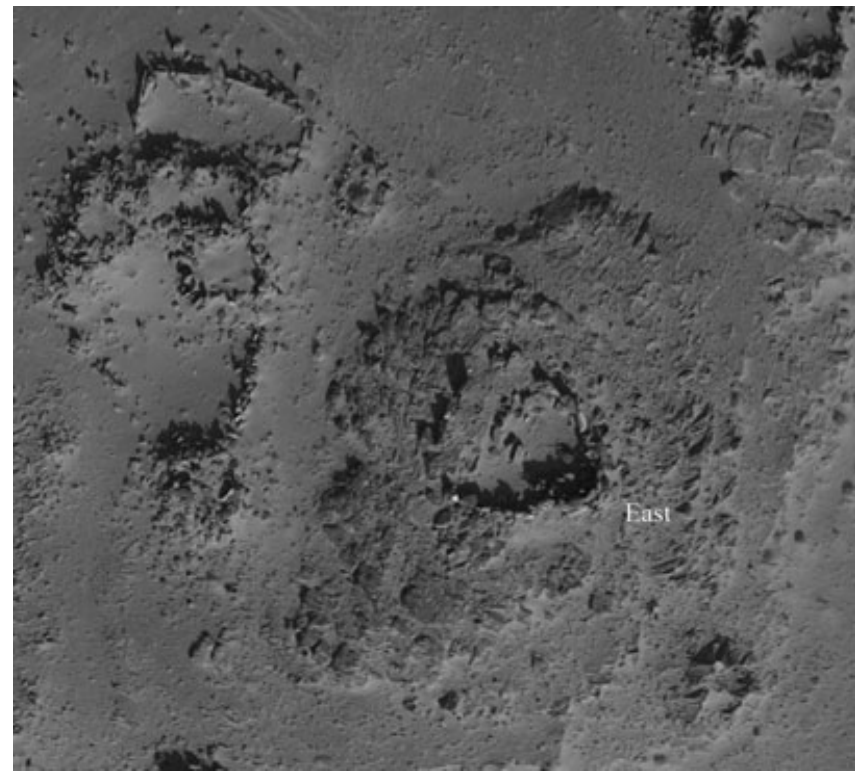

Fig. 5.

The chapel.

chapel (Fig. 5). We discovered a stone engraved with a decorative cross (Fig. 6).

These heaps are settled on a plot of land which is rather large and not very high, forming a triangle: in its southern part lies the Al-qā' depression. Some remains to the south of the site are related to a water damming system, as was reported by Horsfield, Horsfield and Glueck (1933: 383). In the narrow plain that lies between the hills and the site, three water channels arrive from the north-west plain and flow into the Al-qā' depression. The $q \bar{a}^{\prime}$ is bound on the western side by a large dike and on the southern and eastern edges by a man-made hill (see Fig. 2).

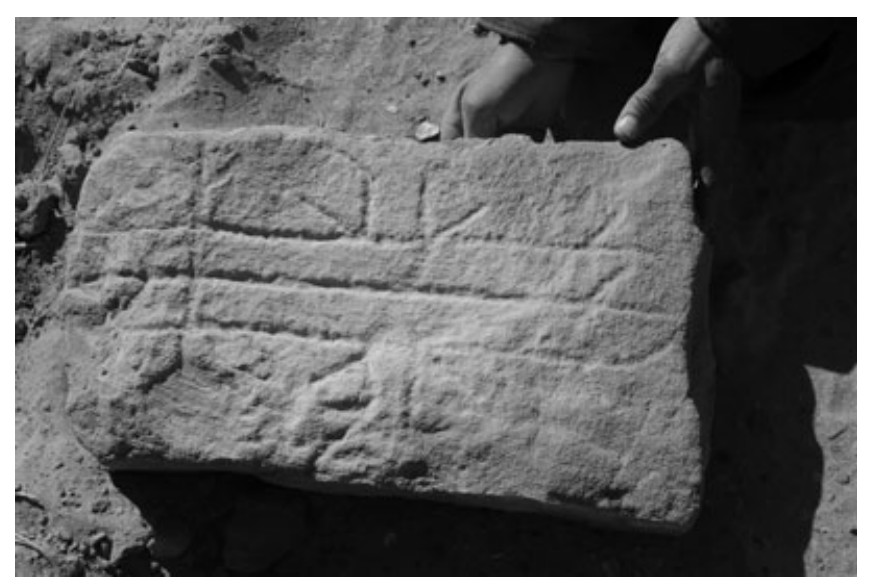

Fig. 6.

Decorated cross from the chapel.

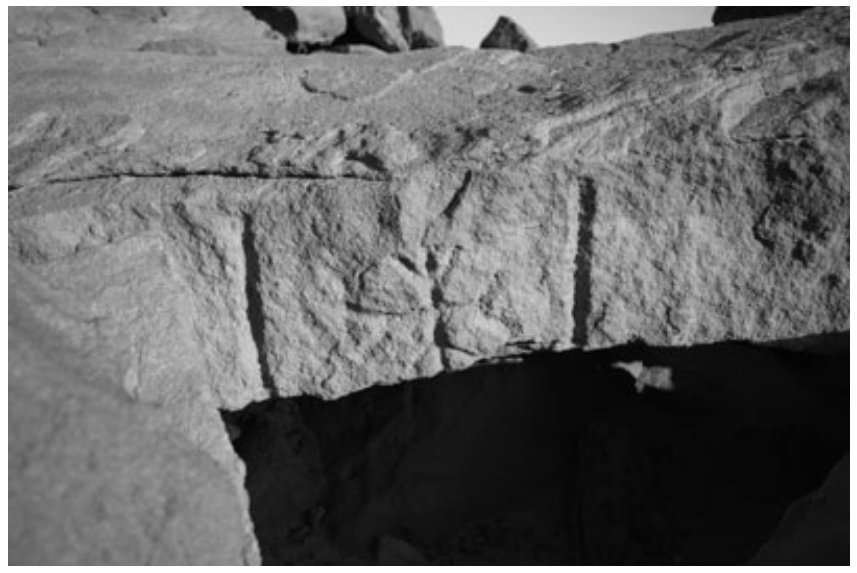

Fig. 7.

Lintel with cross.

There are two different construction systems: the buildings on the south-western side were constructed of dry carved stones (see Fig. 2/J) cemented with lime; the cell and the chapel were built of uncarved dry stones. In some cells the lintels bear crosses (Fig. 7).

\section{The outer area of the Kilwa settlement}

These remains spread into the nearby hills. There is a troglodyte hermitage within $c .30 \mathrm{~m}$, to the south-east of the monastic settlement. The remains were reported by Horsfield, Horsfield and Glueck (1933: 383) and consist of a solid mass built like an altar, with several crosses engraved in the rock, and a sacked tomb.

\section{Description of the remains}

The monastic dwellings

The aerial photographs enabled us to distinguish the following:

Zone A, to the south-west of the site (Fig. 2/J). This zone is made up of three buildings:

- the first building, measuring approximately $8 \mathrm{~m}^{2}$ (Fig. $2 / \mathrm{J}$, no. 46), designated 'the double building', is divided into two parts by a central wall. These two elements have neither windows nor doors. They seem to be hollowed out below. It is undoubtedly a tank to retain the rainwater flowing from the wadis to the north-west of the site. The water is conveyed by a series of three stone channels coming to an end at the first building. The walls, covered with mortar, are built of corbelled paving stones and are topped with a floor to create a two-storied building. The foundations are regular. Two columns stand inside the building to the 


\section{SABA FARÈS}

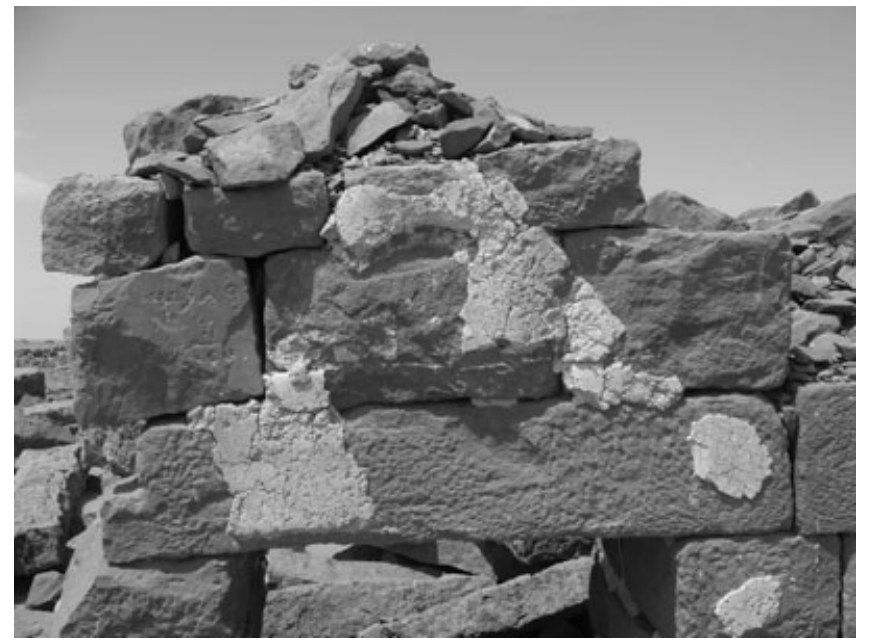

Fig. 8 .

Door decoration, ST 48.

north. A circular structure has been added to the southern wall but its function is unknown.

- the second rectangular building parallel to no. 46 (Fig. $2 / \mathrm{J}$, no. 47) is made up of two levels built using the same technique, i.e. a corbelled paving stone construction topped with a floor. Access to this building is through a door in the southern wall. There are other openings in the western wall.

- raised using the same building technique as the two previous ones, only one level of the third rectangular building parallel to nos. 47 and 46 (Fig. 2/J, no. 48) remains intact. Here too, the building is made up of two rooms with one door each. One of the doors bears a recent Arabic inscription. A space links buildings 47 and 48. The remains of a decoration, triangular in form, were observed at the top of the door (Fig. 8). There appears to be an icon of a saint incrusted in the mortar remains. ${ }^{1}$

Zone B: in the southern centre of the site (Fig. 2/A, G) there is a $15 \mathrm{~m}^{2}$ space filled with ash (Fig. 2/A, no. 57). Nearby we can distinguish traces of buildings, visible on the aerial photograph, and abundant mortar. To the northeast of that space stands a construction similar in dimension to the ash-filled space $(15 \times 15 \mathrm{~m})$ (Fig. $2 / \mathrm{G}$, no. 54). The remains of the wall suggest a church with an apse facing east.

Zone $\mathrm{C}$, to the east (Fig. 2/C): this zone borders a shallow wadi. There is a group of four or five construc-

1 The remains do not enable us to determine whether the image is male or female. Further excavation may provide us with additional information.

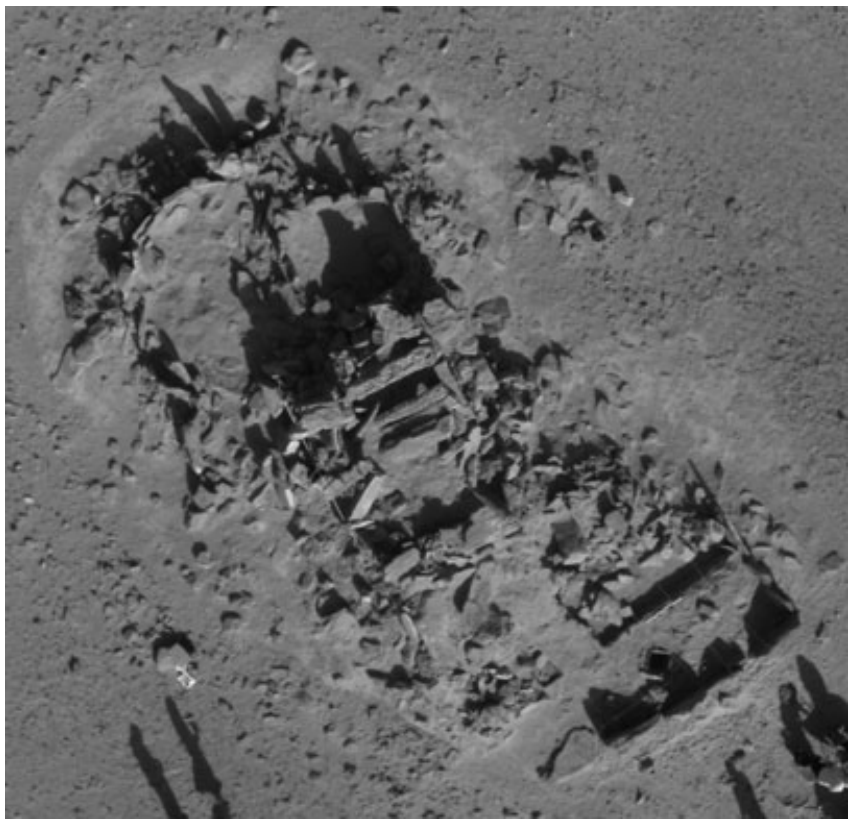

Fig. 9.

Aerial view of ST 63

tions surrounding a sixth, which is built on higher rocky ground. The latter is a rectangular construction with an apse facing east. We were able to extricate a stone from the ground bearing a simplified engraving of a cross. The building was probably a chapel (Fig. 5).

Zone D: this zone, an extension of the one on which the hermitage cells are located, is rather fragmented (Fig. 2/B, D, E, F, H and I). There are about forty elements gathered into smaller groups of four to eight cells, built with rough dry stones. The architecture is difficult to determine with precision but the manner in which it has collapsed leads us to think that it was a vaulted building. In general, the basic cell plan is composed of a yard of varying shape and a room whose door lintel is topped with a cross. We noticed a large diversity of architecture although there was always a yard before the cell.

\section{Excavation results of the 2009 campaign}

This initial work enabled us to understand better the layout of the site and, in particular, the structures and their possible uses. On the basis of the documentary work we were able to begin excavation of structure 63 in $2009^{2}$ and a topographical map of the site was drawn up.

\footnotetext{
2 A report of the excavation is published in Farès, in press, a.
} 


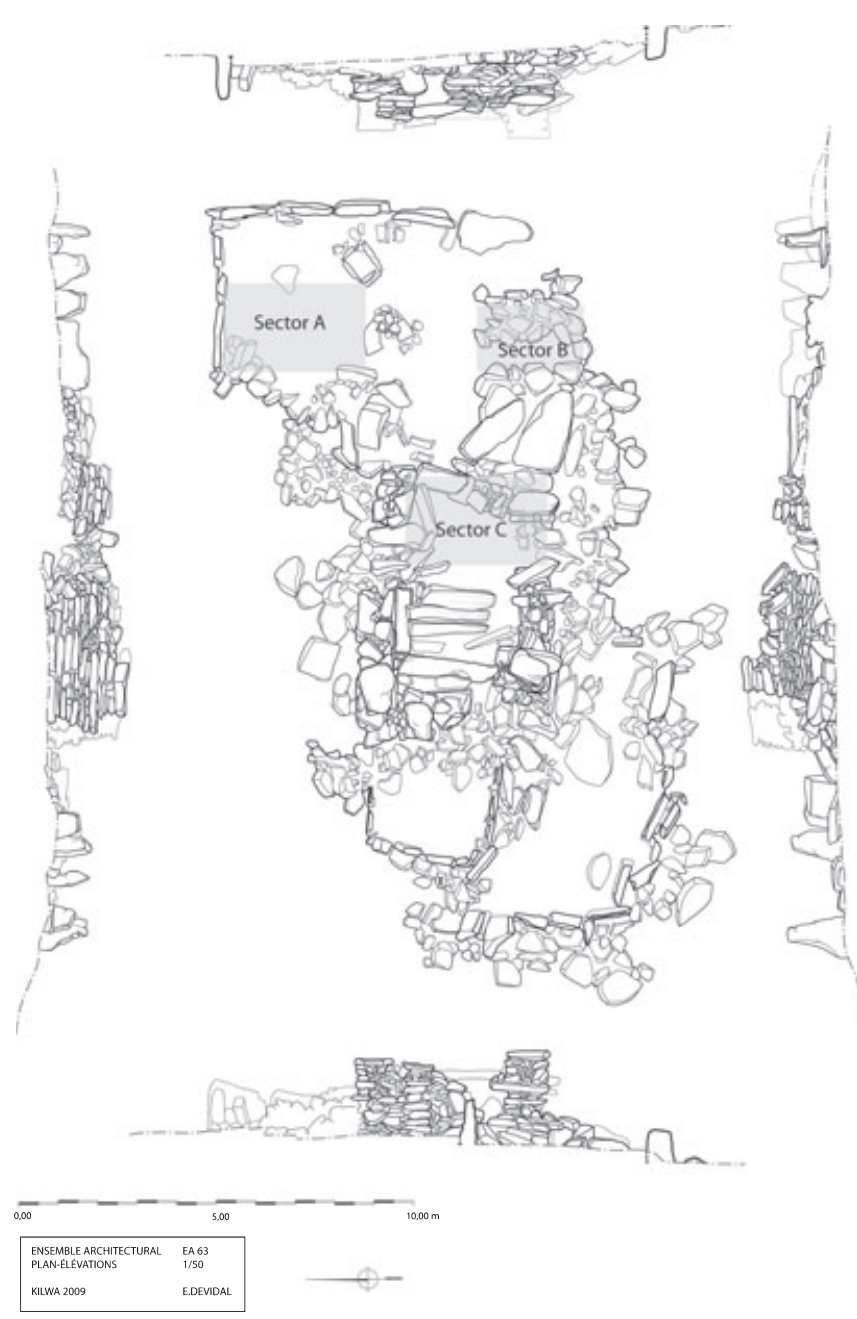

Fig. 10 .

Localisation of sectors A, B and C.

Structure 63 is the site's most valuable cell (see Figs 2 and 9) due to the quality of its architectural remains, characterised by huge walls which have remained standing, and the lintel with the cross and its Islamic inscription. In 2009, the excavation zone was divided into three sectors: A, B and C (see Fig. 10).

\section{Sector A}

The purpose of excavating this $8 \mathrm{~m}^{2}$ area was to clarify the link between the building and the area delimited by the upright slabs. There are two perceivable stratigraphic units: the collapse layer (SU 1) and the soil level - the habitation level - composed of calcite and sand (SU 6) (Fig. 11). The slabs stand upright on the original ground. Some pottery sherds and bone fragments were discovered.

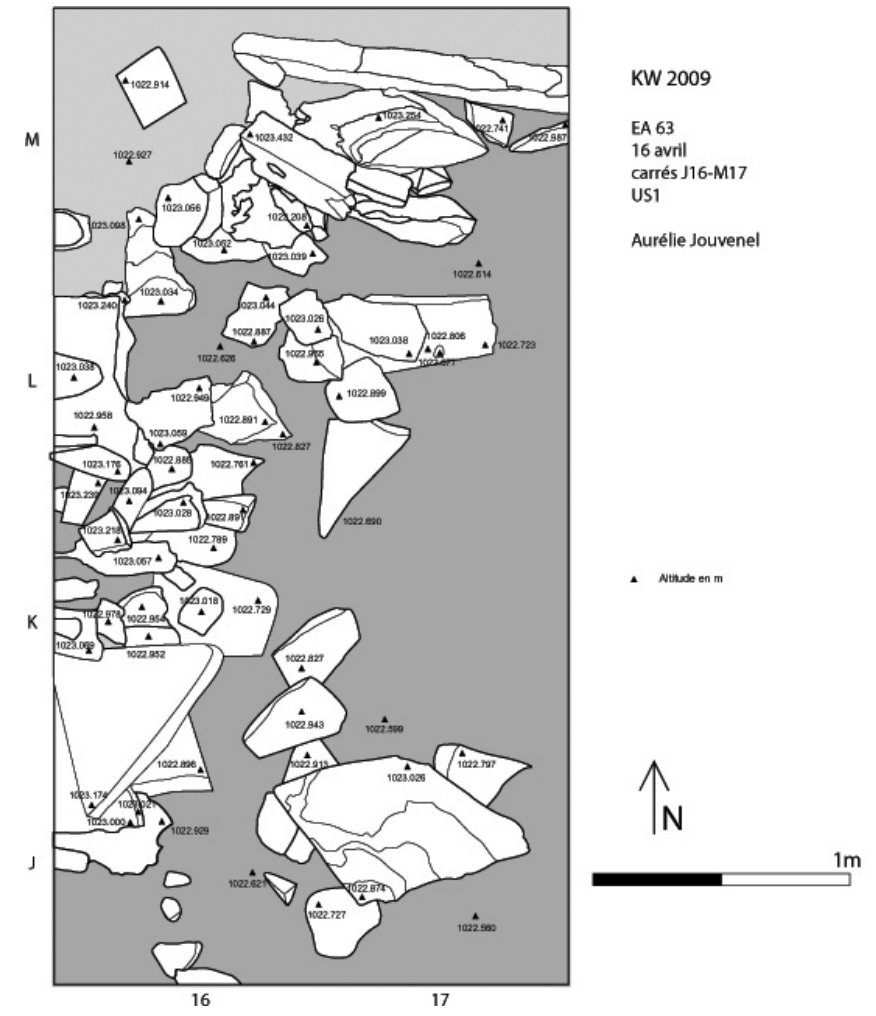

Fig. 11.

Sector A, US 1 and 6.

Sector B

Sector B was opened up over $6 \mathrm{~m}^{2}$ to determine the limits of the SU 3 wall and to identify the relationship between the wall and the rest of the building. A rough semi-circular construction was revealed, formed by walls on three sides. They are all built of dry stone, composed of five layers of stone. An ash layer (SU 7) 1 to $2 \mathrm{~cm}$ thick was discovered at ground level (SU 8) (Figs 12 \& 13).

In Sector B numerous ceramic sherds were discovered in the ashy layer (SU 7) resting on a floor. Most of the ceramics are decorated by incision. Burnt stones were also collected for analysis and some bone fragments were found.

\section{Sector $C$}

This is the entrance to the cell. The excavated area covers $4 \mathrm{~m}^{2}$. We excavated down to the clay soil level. Dry-stone walls over $1 \mathrm{~m}$ in height remain intact. Door jambs, one of which is still in place, were made with stones and a monolith served as a lintel (Fig. 14). The entrance was closed off by two stones, probably during a later period of occupation. 


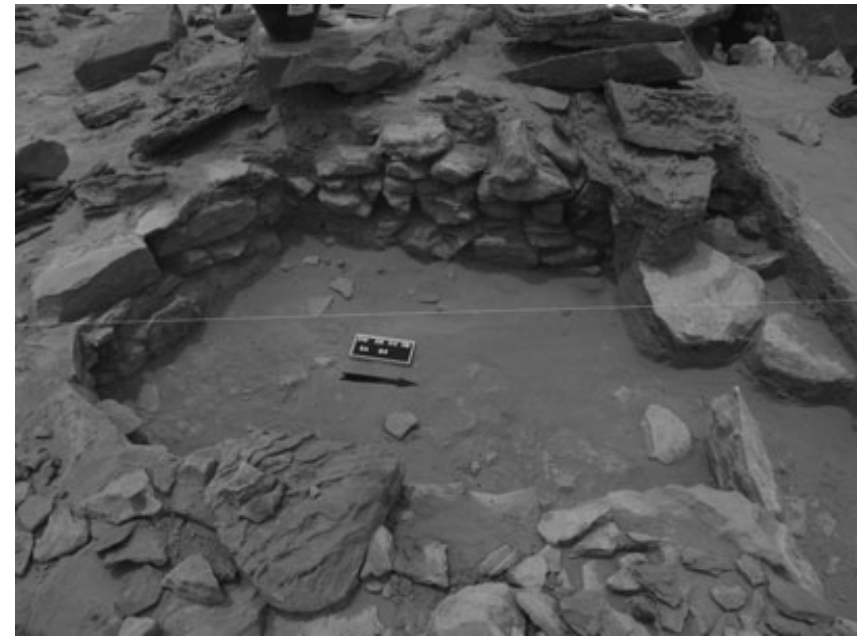

Fig. 12.

Sector B during excavation.

\section{KW 2009}

\section{EA 63}

26 avril

carrés F16-H17

US3-US14

Aurélie Jouvenel

16

17

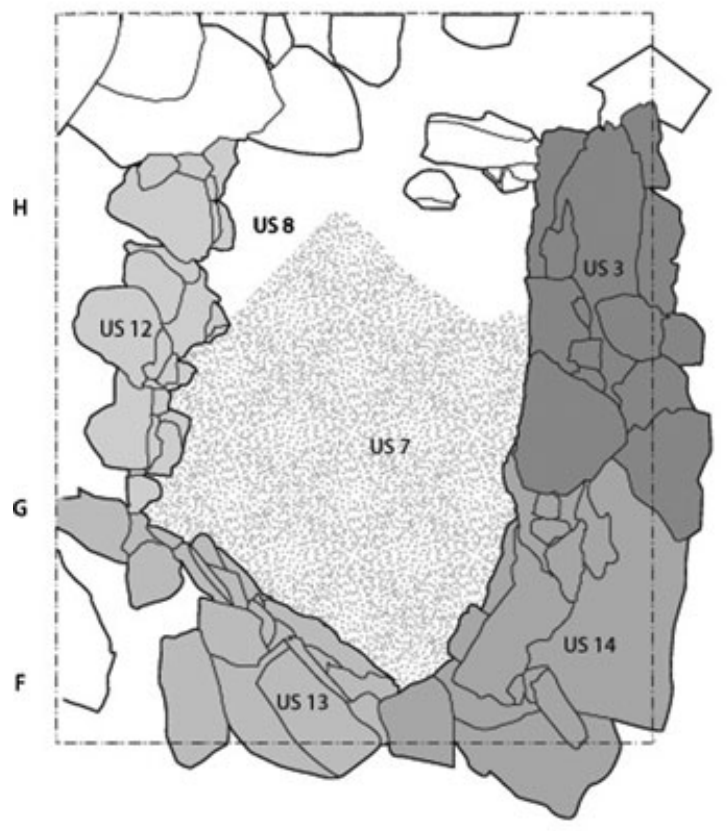

$\uparrow_{\mathrm{N}}$

Fig. 13.

Sector B, final plan.

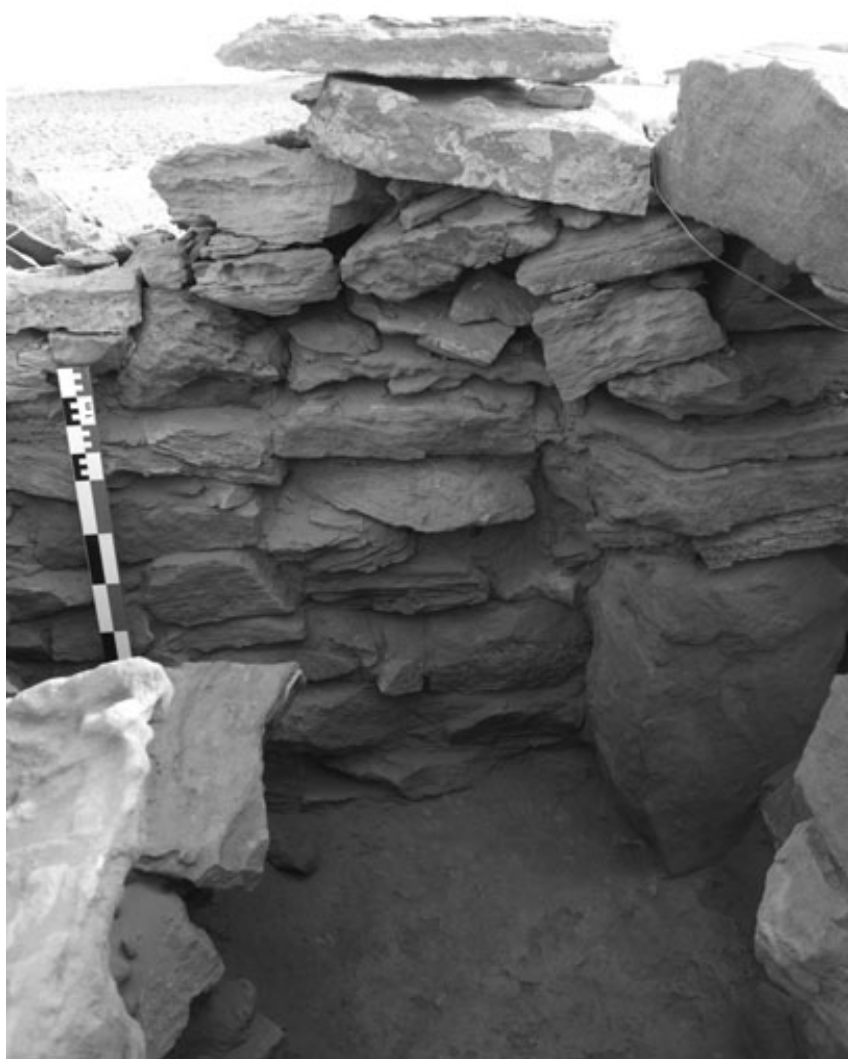

Fig. 14.

Sector C, height of the wall.

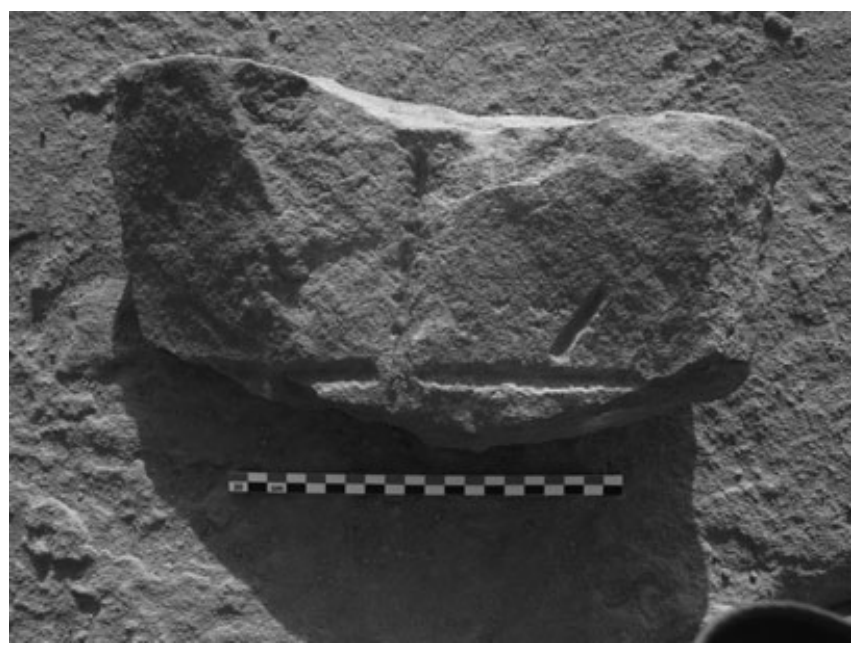

Fig. 15.

Fragment of cross.

Some of the ceramic sherds from the collapse layer have been identified. A stone engraved with a cross was discovered in the front door, outside the cell (Fig. 15). 

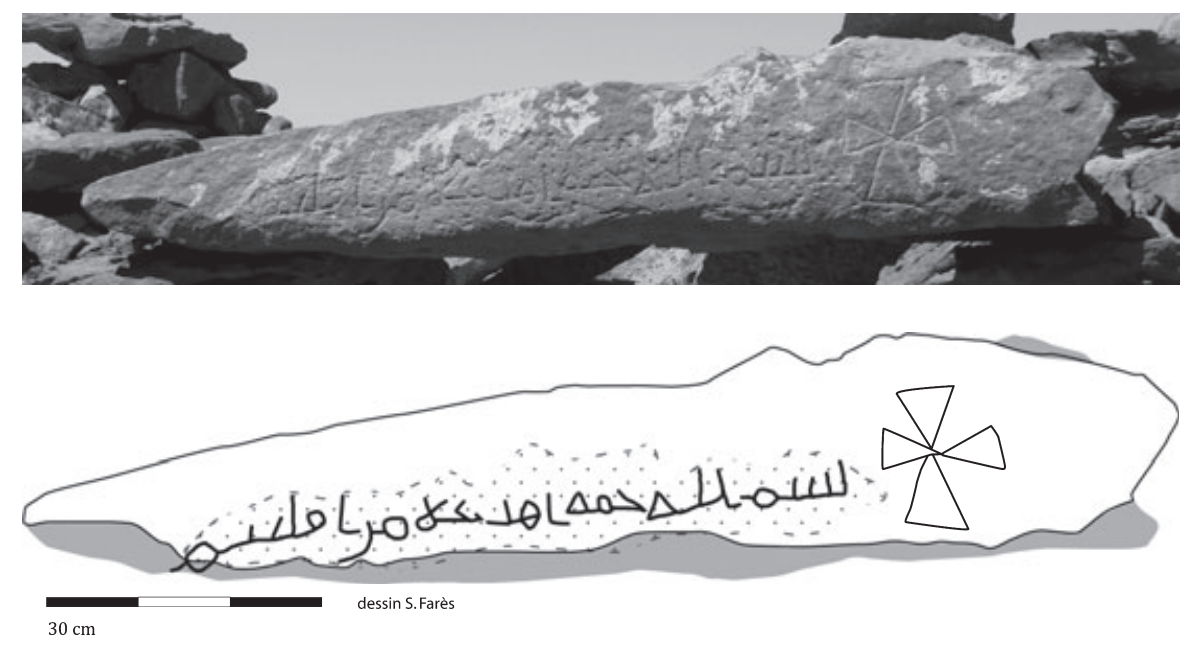

Fig. 16.

Arabic inscription (photograph and facsimile).

Bone remains were discovered in the collapse layer (SU 9).

The date of occupation of this monastery will remain undetermined until the final outcome of the studies of the excavated materials is known. In the meantime, we might base our assumptions on the Arabic inscription found on the lintel of cell 63 (Fig. 16, photograph and facsimile) ${ }^{3}$ which translates as follows:

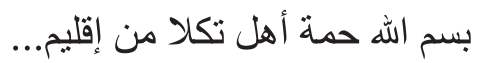

\section{Bism Allâh himat 'hl Taklâ min 'Iqlîm}

In the name of God, this is 'the forbidden land, the irrigated field', belonging to the community of Takla, originally from Iqlīm.

The first remark we would like to make concerns the script. It is identical to the inscription at Qașr Burqu', dated $81 \mathrm{AH} / \mathrm{AD} 700$ by the Omayyad caliph, al-Walīe, before his ascension to the throne (AD 705-715). According to Savignac's observations, the lettering of the text resembles script dating from about AD 1000 (Horsfield, Horsfield \& Glueck 1933: 381). Unlike the text of Qasr Burqu', we owe this text to Christians: the name of the saint is clear from the reading (Takla). The name seems to refer to Thecla (Takla), the famous saint whose cult flourished in Seleucia and Syria during the fourth and fifth centuries (Davis 2001). The origin of this community, according to the text, is Iqlīm, which means 'province,

3 The text is the object of an article in Farès, in press, b. district, or county' in Arabic, but also refers to a place in southern Syria. Iqlīm is mentioned in al-Qalānisī, Dayl Tā'rîh Dimašq (The Continuation of the Chronicle of Damascus). For Gibb, who translated some extracts from the book of al-Qalānisī, 'the district which fits the description is that along the Nahr al-A'waj, now called Iqlīm Ballān' (2002: 345, n. 1).

Himat means 'the forbidden place' in Arabic. It occurs in Lisan al-'arab to designate a protected area for farming, grazing camels or an area that collects rain and is reserved for a group of farmers. ${ }^{4}$ Future studies will perhaps provide us with further information on this question. To conclude, we should add that as it is not unusual for Christian inscriptions to begin with the basmala it is not an indication that the author of the inscription is more likely to have been a Muslim rather than a Christian. ${ }^{5}$

The monastery is important because it is one of the rare monasteries lying in the extreme south of Transjordan (and the site of the only Christian presence to be found as one nears the west of the Arabian Peninsula).

The people of this region knew how to adapt their habitat to the arid environment. Thus it is important for us to understand the strategies determining the physical layout of the space that was occupied. Nomads severely restrict access to resources (Farès 1995), and people can

4 The Hima system is known in the arid region and has been mentioned in a large number of publications. For more details on this system see Bocco 1993: 349-353 and Draz 1985: 109121.

5 For a discussion see Farès, in press, $b$. 


\section{SABA FARÈS}

move freely and tap into natural resources only if a contract has been established between community members and the indigenous population.

The environment is at the heart of the study. How was this community able to survive in such a hostile environment? The Al-qā' indicates that a sophisticated hydraulic system was set up but was it enough to survive? Did the monks raise crops? Fieldwork remains crucial and the material discovered in the excavations and the archives may well provide us with important answers. The monastery of Kilwa, which still retains much of its mystery, may very well help us to gain a greater understanding of the expansion of Islam and its behaviour towards other communities, in this case Christianity. It is essential to stress that the crosses in Kilwa, more than ten in number, are all in very good condition, as are those in Qașr Burqu' (Gaube 1974: 98; Field 1960), and that this Christian symbolism has never been damaged. Further work on Kilwa will improve our knowledge of the historical geography of Arabia at the beginning of Islam, and will help us to understand the spatial organisation adopted by nomadic peoples in arid areas. This work cannot achieve its goal without taking into consideration the social and political levels on which the monastery operated.

\section{References}

Bell, G. 1914. A Journey in Northern Arabia. The Geographical Journal 44/1: 76-77.

Bocco, R. 1993. De la sécurité politique à l'autonomie alimentaire dans les steppes: experts internationaux et programmes de développement (1950-1990). Pages 326353 in Bocco R., Jaubert R. \& Métral F. (eds.), Steppes d'Arabie, Etats, pasteurs, agriculteurs et commerçants: le devenir des zones sèches (Genève, Cahier de l'I.U.E. D.).

Breasted, J.H. \& Debevoise, N.C. 1934. The Oriental Institute Archaeological Report on the Near East. The American Journal of Semitic Languages and Literatures 50/3: 184.

Davis, S.J. 2001. The Cult of Saint Thecla: A Tradition of Women's Piety in Late Antiquity. Oxford: Oxford University Press.

Draz, O. 1985. The Hema system of range reserves in the Arabian Peninsula. Its possibilities in range improvement and conservation projects in the Near East. Pages 109-121 in McNeely J.A. \& Pitt D. C. (eds.), Culture and conservation: the human dimension in environmental planning (Worcester, Billing and Sons Limited).

Farès, S. 1995. L'inscription de type dédanite d'Abu al-Dibâ'/Wady Ramm, une nouvelle lecture. $A D A J$ 39: 493-497.
Farès, S. in press. a. Kilwa, preliminary report of the 2009 season of the Saudi-French team at Kilwa. Atlal 22.

Farès, S. in press. b. L'inscription arabe de Kilwa: nouvelle lecture. Semitica et Classica 3.

Field, H. 1960. North Arabian desert archaeological Survey 1925-50. Cambridge, MA: Peabody Museums, Papers XLV, 2.

Gaube, H. 1974. An Examination of the Ruins of Qasr Burqu'. Annual of the Department of Antiquities of Jordan 19: 93-100.

Gibb, H.A.R. 2002. The Damascus Chronicle of the Crusades: Extracted and Translated from the Crusades. Extracted and translated from the Chronicle of Ibn al-Qalânisî. (Reprint). Dover Publications.

Glueck, N. 1936. Christian Kilwa. Journal of the Palestine Oriental Society 16: 9-16.

Graf, D. 1999. Roman Roads East of the Jordan. Pages 230-234 in Piccirillo M. \& Alliata E. (eds.), The Madaba Map Centenary 1887-1997: Travelling Through the Byzantine Umayyad Period (Jerusalem, Studium Biblicum Franciscanum).

Horsfield, A. 1943. Journey to Kilwa, Transjordan. The Geographical Journal 102/2: 71-77.

Horsfield, G., Horsfield, A. \& Glueck, N. 1933. Prehistoric Rock-Drawings in Transjordan.
American Journal of Archaeology 37/3: 381-386.

Howe, B. 1950. Two Groups of Rock Engravings from the Hijaz. Journal of Near Eastern Studies 9/1: 8-17.

Ingraham, M.L., Johnson, T.D., Rihani, B. \& Shatla, I. 1981. Preliminary Report on a Reconnaissance Survey of the North-western Province (with a Note on a Brief Survey of the Northern Province). ATLAL 5: $59-83$.

Rhotert, H. 1938. Transjordanien: Vorgeschichtliche Forschungen. Stuttgart: Strecker and Schroeder.

Sartre, M. 1981. La frontière méridionale de l'Arabie romaine. La géographie administrative et politique d'Alexandre à Mahomet (Actes du colloque de Strasbourg, 14-16 juin 1979): 77-92.

Stein, A. 1940. Surveys on the Roman Frontier in Iraq and Trans-Jordan. The Geographical Journal 95/6: 435.

al-Taymani, H., Ghabban, A., al-Saud, S. \& Khan, M. 2003. Antiquities of Tabuk. Vol. 8. Riyadh: Publication of the Deputy Minister for Antiquities and Museums.

Zarins, J. 1990. Early Pastoral Nomadism and the Settlement of Lower Mesopotamia. Bulletin of the American Schools of Oriental Research 280: 31-65. 